\title{
Pengaruh Keadilan Distributif dan Keadilan Prosedural terhadap Kecurangan Akuntansi dengan Pertimbangan Etis sebagai Variabel Moderasi
}

\author{
Ikbal \\ Syamsuri Rahim \\ Universitas Muslim Makassar \\ Jl. Urip Sumoharjo KM.5, Kota Makassar, Indonesia 90231 \\ Ikbal_umi@yahoo.com
}

\begin{abstract}
This study aims to determine the effects of distributive justice and procedural justice on accounting fraud. Furthermore, ethical consideration is also tested as moderating variable in both relationships. Research data is collected by distributing questionnaires to 30 apparatus at SKPD (regional government working unit) in Maros District, and processed with path analysis using SPSS version 23. The result shows that the distributive justice has a positive-significant effect on accounting fraud, and the procedural justice has a negative-significant effect on accounting fraud in SKPD Maros District. This study also finds that the distributive justice does not affect on the tendency of accounting fraud moderated by ethical considerations at SKPD Maros District. In contrary, procedural justice is proved to affect the tendency of accounting fraud moderated by ethical considerations in the Maros District SKPD.
\end{abstract}

Keywords: Accounting Fraud, Distributive Justice, Ethical Considerations, Procedural Justice

\begin{abstract}
Abstrak
Penelitian ini bertujuan untuk menentukan dampak keadilan distributif dan keadilan prosedural pada kecurangan akuntansi. Selain itu, pertimbangan etis juga diuji sebagai variabel moderasi pada kedua hubungan tersebut. Data penelitian dihimpun dengan cara menyebarkan kuesioner kepada 30 aparat di SKPD Kabupaten Maros, dan diolah menggunakan analisis jalur dengan bantuan SPSS versi 23. Hasil penelitian menunjukkan bahwa keadilan distributif memiliki pengaruh positif-signifikan pada kecurangan akuntansi, dan keadilan procedural memiliki pengaruh negative-signifikan pada kecurangan akuntansi di SKPD Kabupaten Maros. Penelitian ini juga menemukan tidak adanya pengaruh pada tendensi kecurangan akuntansi yang dimoderasi oleh pertimbangan etis. Di sisi lain, keadilan procedural terbukti mempengaruhi kecurangan akuntansi saat dimoderasi oleh pertimbangan etis di wilayah SKPD Kabupaten Maros.
\end{abstract}

Kata Kunci: Kecurangan Akuntansi, Keadilan Distribusi, Pertimbangan Etis, Pertimbangan Prosedural

\section{PENDAHULUAN}

Kecurangan atau yang sering dikenal dengan istilah fraud merupakan hal yang banyak dibicarakan di Indonesia. Kecurangan melibatkan penyajian yang keliru dari fakta yang disengaja dan atau untuk memperoleh informasi yang tidak semestinya atau untuk memperoleh keuntungan keuangan illegal. Kesengajaan atas salah pernyataan terhadap suatu kebenaran atau keadaan yang disembunyikan dari sebuah fakta material yang dapat mempengaruhi orang lain untuk melakukan perbuatan atau tindakan yang merugikannya, biasanya merupakan kesalahan namun dalam beberapa kasus (khususnya dilakukan secara disengaja) memungkinkan merupakan suatu kejahatan. Penyajian yang salah/keliru (salah pernyataan) yang secara ceroboh/tanpa perhitungan dan tanpa dapat dipercaya kebenarannya berakibat dapat mempengaruhi atau menyebabkan orang lain bertindak atau berbuat.

Salah satu teori yang menjelaskan tentang motivasi seseorang melakukan fraud adalah Fraud Triangle Theory. Fraud triangle terdiri atas tiga komponen yaitu opportunity, pressure, dan rationalization. Kesempatan atau opportunity merupakan suatu kondisi yang memungkinkan seseorang bisa melakukan kecurangan. Kecurangan akan dilakukan jika ada kesempatan, seseorang harus memiliki akses terhadap aset atau memiliki wewenang untuk mengatur prosedur pengendalian yang memperkenankan dilakukannya skema kecurangan. Jabatan, tanggung jawab, maupun otorisasi memberikan peluang untuk terlaksananya kecurangan (Suprajadi, 2009). 
Salman (2005) dan Kurniawati (2012) menyebutkan bahwa tekanan (pressure) adalah insentif yang mendorong orang melakukan kecurangan karena tuntutan gaya hidup, ketidakberdayaan dalam soal keuangan, perilaku gambling, mencoba-coba untuk mengalahkan sistem dan ketidakpuasan kerja. Tekanan merupakan faktor yang berasal dari kondisi individu yang menyebabkan seseorang melakukan kecurangan. Tekanan dari dalam diri seseorang tersebut dapat dipengaruhi oleh lingkungan tempat bekerja. Salah satu, faktor lingkungan yang dapat menyebabkan tekanan pada seorang pegawai adalah keadilan organisasional dalam perusahaan. Keadilan tersebut berkaitan dengan cara seseorang mendapatkan reward berupa gaji atau kompensasi lain atas pekerjaannya (keadilan distributif) dan prosedur reward (keadilan prosedural). Dalam penelitian ini tekanan atau pressure diproksikan dengan persepsi tentang keadilan prosedural dan keadilan distributif.

Skousen, et al., (2009) menyebutkan bahwa rasionalisasi adalah komponen penting dalam kecurangan, rasionalisasi menyebabkan pelaku kecurangan mencari pembenaran atas perbuatannya. Rasionalisasi merupakan bagian dari fraud triangle yang paling sulit diukur. Budaya organisasi dan komitmen organisasi merupakan faktor yang diduga dijadikan pembenaran pegawai melakukan kecurangan.Pemerintah, pelaku bisnis dan masyarakat telah memahami bahwa fraud dapat merugikan keuangan negara dan keuangan perusahaan, serta merusak sendi-sendi budaya masyarakat. Namun, pimpinan instansi seringkali merasa bahwa organisasinya termasuk lingkungan yang bebas risiko fraud. (Sudarmo, et al., 2008). Fraud di sektor pemerintahan, merupakan sesuatu yang serius karena sumber daya yang terbatas tidak digunakan untuk pelayanan bagi masyarakat atau konstituen dan dampak yang lebih besar dari fraud di instansi pemerintah adalah hilangnya kepercayaan pada kemampuan kepemimpinan instansi pemerintahan.

Sektor bisnis dan sektor pemerintah tidak lepas dari berbagai tindak kecurangan yang dilakukan baik oleh pihak internal maupun eksternal entitas. Pada sektor pemerintah tindak kecurangan lebih dominan dibandingkan sektor bisnis karena sistem pengelolaan keuangan pemerintah bersifat sentralisasi. Namun, sejak reformasi pemerintah dituntut transparan dan akuntabel. Oleh karena itu, pemerintah berupaya membuat regulasi guna memperkuat struktur kelembagaan keuangan, pencegahan dan penanganan tindak kecurangan. Kecurangan yang dilakukan oknum pemerintah sulit terdeteksi karena pelaku merupakan orang yang dipercaya dalam suatu proyek. Oleh karena itu, auditor laporan keuangan harus memiliki keahlian untuk mendeteksi kecurangan. Lebih lanjut, auditor laporan keuangan berfungsi untuk mendeteksi kecurangan, sedangkan pengungkapannya dilakukan oleh auditor forensik.

Indonesia Corruption Watch (ICW) merilis tren penanganan kasus korupsi tahun 2016. Tercatat 482 kasus korupsi berhasil ditangani aparat penegak hukum baik Kejaksaan, Kepolisian, maupun Komisi Pemberantasan Korupsi (KPK) selama tahun 2016. Dari 482 kasus tersebut sudah ditetapkan 1.101 tersangka, dengan kerugian negara sebesar 1,45 triliun dan nilai suap sebesar 31 miliar. Dari jumlah tersebut, 6 kasus diantaranya adalah pengembangan kasus yang dilakukan KPK. Sebagian besar tersangka adalah pejabat/pegawai pemerintah daerah (pemda) dan kementerian, yakni 42,6 persen. Tersangka lain merupakan direktur/komisaris perusahaan swasta, anggota DPR/DPRD, kepala dinas, dan kepala daerah Sebanyak 515 Aparatur Sipil Negara (ASN) telah ditetapkan sebagai tersangka korupsi oleh aparat penegak hukum pada 2016. ASN/PNS yang disidik karena terlibat korupsi sebagian besar berasal dari Pemerintah Daerah (Kabupaten/Kota). Fenomena korupsi birokrasi, khususnya paska penerapan desentralisasi menjelaskan gagalnya agenda reformasi birokrasi dan buruknya pengawasan pusat atas daerah (Dokumen ICW).

Kabupaten Maros adalah salah satu kabupaten dengan nilai korupsi yang sangat besar. Beberapa kasus diantaranya; kasus dugaan korupsi pemasangan lampu jalan senilai Rp 1,4 miliar, kasus dugaan korupsi dana komite dan Bantuan Operasioal Sekolah (BOS) SMA 10 Simbang Maros tahun 2012-2015 dengan perkiraan kerugian negara mencapai Rp 785 juta, kasus dugaan korupsi bedah rumah di Kelurahan Baji Pammai dengan perkiraan kerugian negara sebesar Rp 651 juta, kasus dugaan korupsi dana alokasi khusus (DAK) 2009 senilai Rp 7 miliar, dan kasus korupsi proyek pembangunan intake dan jaringan air baku Jamala dengan perkiraan kerugian negara sebebsar Rp 2 miliar. 
Ivancevich, et al., (2006) menyebutkan bahwa berdasarkan teori atribusi, penyebab yang dipersepsikan dari suatu peristiwalah dan bukan peristiwa aktual itu sendiri yang memengaruhi perilaku seseorang. Secara lebih spesifik, individu akan berusaha menganalisis mengapa peristiwa tertentu muncul dan dari hasil analisis tersebut akan mempengaruhi perilaku mereka di masa mendatang. Proses atribusi juga dapat menjadi hal yng penting dalam memahami perilaku dari orang lain. Perilaku orang lain dapat diperiksa atas dasar keunikan, konsistensi dan konsensus. Keunikan merupakan tingkatan di mana seseorang berperilaku secara serupa dalam situasi yang berbeda. Konsistensi merupakan tingkatan dimana seseorang menunjukkan perilaku yang sama pada waktu yang berbeda. Konsensus merupakan tingkatan dimana orang lain menunjukkan perilaku yang sama. Mengetahui sejauh mana perilaku seseorang menunjukkan kualitas ini dapat sangat bermanfaat dalam membantu memahami perilaku tersebut. Oleh karena itu, penelitian ini bertujuan untuk menguji pengaruh keadilan distributif, keadilan prosedural, dan moderasi etika sektor publik terhadap kecurangan akuntansi.

\section{Pengaruh Keadilan Distributif terhadap Kecurangan Akuntansi}

Persepsi mengenai keadilan distributif merupakan persepsi mengenai kesesuaian gaji atau kompensasi lain yang diterima oleh pegawai dibandingkan dengan apa yang telah diberikan kepada organisasi. Persepsi mengenai keadilan ini dibandingkan dengan orang lain yang setara. Jika seseorang mempersepsikan bahwa terdapat ketidakadilan mengenai gaji atau kompensasi yang seharusnya didapatkan maka akan mendorong orang tersebut melakukan kecurangan. Akan terjadi tekanan dalam dirinya berkaitan dengan ketidakadilan yang dipersepsikan sehingga mendorong untuk melakukan tindakan-tindakan kecurangan. Keadilan distributif merupakan sebuah persepsi tentang nilai yang diterima oleh pegawai berdasarkan penerimaan suatu keadaan atau barang yang mampu mempengaruhi individu (Supardi, 2008). Penghargaan dan sumberdaya tersebut diproksikan dengan gaji atau kompensasi lain yang seharusnya diterima oleh pegawai. Indikator keadilan distributif $\left(\mathrm{X}_{1}\right)$ adalah kompensasi diberikan organisasi sesuai dengan kinerja pegawai. Keadilan prosedural merupakan pertimbangan yang dibuat oleh karyawan mengenai keadilan yang dipersepsikan mengenai proses dan prosedur organisasi yang digunakan untuk membuat keputusan alokasi dan sumber daya (Ivancevich, et al., 2006). Prosedur yang dimaksud adalah prosedur mengenai proses pengambilan keputusan berkaitan dengan gaji atau kompensasi lain yang akan diterima oleh pegawai.Berdasarkan uraian diatas, maka dapat dihipotesiskan:

$\mathrm{H}_{1}$ : Keadilan distributif berpengaruh positif terhadap kecurangan akuntansi

\section{Pengaruh Keadilan Prosedural terhadap Kecurangan Akuntansi}

Menurut Thibaut \& Walker (1975), serta Kadaruddin dkk (2012) keadilan prosedural mengacu pada kesetaraan prosedur. Prosedur dinilai sebagai adil jika mereka diimplementasikan konsisten, tanpa kepentingan pribadi, berdasarkan informasi yang akurat, dengan kesempatan untuk memperbaiki keputusan itu, dengan kepentingan semua pihak diwakili, dan mengikuti moral dan etika standar. Indikator keadilan $\left(\mathrm{X}_{2}\right)$ adalah prosedur kompensasi mengekspresikan pandangan dan perasaan, penetapan prosedur kompensasi melibatkan karyawan, prosedur kompensasi diaplikasikan secara konsisten, prosedur kompensasi tidak mengandung kepentingan tertentu, prosedur kompensasi didasarkan pada informasi yang akurat, prosedur kompensasi memungkinkan pemberian masukan dan koreksi. Berdasarkan uraian diatas, maka dapat dihipotesiskan:

$\mathrm{H}_{2}$ : Keadilan prosedural berpengaruh negatif terhadap kecurangan akuntansi

\section{Moderasi Pertimbangan Etis}

Widodo (2001) menyebutkan bahwa etika sektor publik didefinisikan sebagai pedoman, referensi, petunjuk yanh harus dilakukan oleh aparatur pemerintah dalam menjalankan kebijakan publik, dan dapat digunakan sebagai standar penilaian perilaku aparatur pemerintah dalam menjalankan kebijakan publik. Organisasi yang baik akan memiliki dan mengamalkan nilai-nilai yaitu kejujuran, keterbukaan, loyalitas kepada organisasi tersebut, kerjasama yang baik, didiplin dan tanggung jawab. Keadilan distributif dan keadilan prosedural dapat dikatakan sebagai faktor yang dapat mempengaruhi kecenderungan kecurangan akuntansi. 
Pegawai yang merasa puas dan merasa adil dengan keadilan distibutif dan keadilian prosedural akan memperlihatkan tingkat kehadiran yang tinggi, kerja sama yang erat, kualitas pelayanan yang baik, kreativitas dalam mencari metode baru dan lebih produktif bila dibandingkan dengan pegawai yang tidak puas dengan situasi mereka. Oleh karena itu pertimbangan etika sebagai variabel moderasi antara keadilan distributif dan keadilan prosedural terhadap kecenderungan kecurangan akuntansi karena seorang pegawai yang mempunyai pertimbangan etika yang tinggi akan lebih bertanggung jawab terhadap organisasinya dan akan meminimalisir terjadinya kecurangan (fraud). Etika sektor publik didefinisikan sebagai pedoman, referensi, petunjuk tentang apa yang harus dilakukan oleh aparatur pemerintah dalam menjalankan kebijakan-kebijakan publik, dan dapat digunakan sebagai standar penilaian apakah perilaku aparatur pemerintah dalam menjalankan kebijakan-kebijakan publik dapat dikatakan baik atau buruk (Widodo, 2001). Indikator pertimbangan etis $\left(\mathrm{X}_{3}\right)$ adalah nilai efisiensi, nilai membedakan milik pribadi dengan milik kantor, nilai impersonal, nilai merytal system, dan nilai responsibel. Berdasarkan uraian diatas, maka dapat dihipotesiskan :

$\mathrm{H}_{3}$ : Etika memoderasi pengaruh keadilan dsitributif terhadap kecurangan akuntansi.

$\mathrm{H}_{4}$ : Etika memoderasi pengaruh keadilan prosedural terhadap kecurangan akuntansi.

\section{METODE}

Penelitian ini menggunakan metode pendekatan kuantitatif karena data yang diambil dalam melakukan penelitian berupa angka-angka serta menggunakan analisis statistik dengan tujuan menguji hipotesis yang telah ditetapkan. Penelitian ini dilakukan pada Satuan Kerja Perangkat Daerah (SKPD) yang berada di Pemerintah Kabupaten Maros. Penelitian ini menggunakan data kuantitatif. Data kuantitatif merupakan data yang berbentuk angka-angka (Sugiyono, 2009). Data yang diperoleh dari pernyataan responden yang dinyatakan dalam angkaangka meliputi skor nilai dari jawaban responden dalam kuesioner penelitian. Sumber data yang digunakan dalam penelitian ini adalah data primer dengan menggunakan metode survey melalui penyebaran kuesioner secara langsung kepada responden. Teknik pengambilan sampel pada penelitian ini menggunakan rumus Taro Yamane.

Analisis deskriptif digunakan untuk memberikan gambaran umum demografi responden, selanjutnya dilakukan uji kualitas data dengan menggunakan uji validitas dan reliabilitas. Pengujian dilakukan terhadap item pertanyaan yang valid. Secara umum suatu instrument penelitian dikatakan bagus jika memiliki koefisien Cronbach's Alpha > 0,60, maka kuesioner penelitian dinyatakan reliabel. Setelah uji kualitas data, selanjutnya dilakukan uji asumsi klasik yang terdiri dari uji normalitas, uji heteroskedastisitas, dan uji multikolinieritas. Pengujian normalitas dalam penelitian ini dapat dilihat dari Normal Probability Plot. Uji heteroskedastisitas merupakan cara untuk mendeteksi ada atau tidaknya masalah heteroskedastisitas adalah dengan melakukan uji Glejser. Uji multikolinieritas dilihat nilai tolerance, jika lebih rendah dari 0,10 maka terjadi multikolinearitas. Sedangkan hasil perhitungan nilai VIF, jika memiliki nilai VIF kurang dari 10, maka tidak mempunyai persoalan multikolinieritas. (Ghozali, 2009).

Model analisis data dan uji hipotesis dalam penelitian ini adalah model analisis regresi sederhana dan model analisis moderasi (Moderated Regression Analysis). Analisis regresi ini merupakan aplikasi khusus regresi linier berganda, dalam persamaan regresinya mengandung unsur interaksi (perkalian dua atau lebih variabel independen). Bentuk regresi ini dirancang untuk menentukan hubungan antar dua variabel yang dipengaruhi oleh variabel moderasi (Suliyanto, 2011).

\section{HASIL DAN PEMBAHASAN}

Kuesioner disebarkan kepada 30 SKPD Kabupaten Maros dengan jumlah pegawai SKPD 98 orang yang terpilih sebagai responden dan dilakukan satu tahap. Sesuai dengan waktu yang telah ditentukan, kuesioner dijemput kembali ke masing-masing responden. Dari 98 kuesioner yang diantarkan, yang kembali adalah 90 kuesioner dengan responden rate sebesar 91,83 persen. Dasar pengukuran validitas instrumen adalah dengan menggunakan indeks korelasi validitas soal, dengan ketentuan korelasi product moment $\mathrm{r}_{\text {hitung }}$ lebih besar dari $\mathrm{r}_{\text {tabel }}$, maka instrumen dikatakan valid. Jumlah responden kuesioner sebanyak 90 responden sehingga diperoleh $r_{\text {tabel }}$ sebesar 0,210 dari hasil koefisien korelasi product moment tiap butir instrumen lebih besar dari $r_{\text {tabel }}$. Sehingga, bisa 
disimpulkan bahwa instrumen valid. Uji reliabilitas dinilai melalui besarnya koefisien Alpha Cronbach. Hasil uji reliabilitas instrumen menunjukan bahwa semua variabel memiliki koefisien Alpha Cronbach lebih besar dari 0,60. Jadi, instrumen keadilan distributif, keadilan prosedural, pertimbangan etis, dan kecurangan akuntansi adalah reliabel.

Uji normalitas sebaran data dilakukan pada setiap variabel. Uji normalitas data menggunakan grafik normal probability plot, dengan kesimpulan data mempunyai distribusi normal karena data menyebar pada sepanjang garis diagonal. Inflating Factors (VIF) ketiga variabel bebas adalah: keadilan distributif sebesar 1,259, keadilan prosedural sebesar 1,115, dan variabel moderator pertimbangan etika sebesar 1,382. Hasil tersebut menunjukkan nilai VIF lebih kecil dari 10 dan nilai toleransinya lebih besar dari 0,1 . Hal ini menunjukkan bahwa tidak terjadi multikolinearitas. Uji heteroskedastisitas menggunakan grafik, hasilnya menunjukkan bahwa titik menyebar secara acak, serta tidak membentuk sebuah model atau pola tertentu di atas dan di bawah angka 0 pada sumbu $\mathrm{Y}$, sehingga dapat disimpulkan tidak heterokedastisitas pada model regresi.

Hipotesis pertama yang di ajukan dalam penelitian ini adalah keadilan distributif berpengaruh positif terhadap kecurangan akuntansi. Hasil analisis regresi untuk menguji hipotesis pertama di sajikan dalam Tabel 1.

Tabel 1. Pengaruh Keadilan Distributif Terhadap Kecurangan Akuntansi

\begin{tabular}{cccccc}
\hline \multicolumn{1}{c}{$\begin{array}{c}\text { Unstandardized } \\
\text { Coefficients }\end{array}$} & $\begin{array}{c}\text { Standardized } \\
\text { Coefficients }\end{array}$ & & \\
\hline Model & $\mathrm{B}$ & Std. Error & Beta & $\mathrm{t}$ & Sig. \\
\hline (Constant) & 2.266 & .476 & & 4.756 & .000 \\
\hline $\mathrm{X} 1$ & .446 & .111 & .394 & 4.025 & .000 \\
\hline
\end{tabular}

Berdasarkan hasil uji parsial di atas, persamaan regresi pengaruh keadilan distributif terhadap kecurangan akuntansi pada SKPD Kabupaten Maros dapat dituliskan ke dalam persamaan regresi sebagai berikut, kecenderungan kecurangan akuntansi $=2,266+0,446 \mathrm{X}_{1}$. Nilai konstanta 0,446 yang positif dan dapat diketahui nilai t hitung sebesar 4,025 lebih besar dari t tabel 1,662 signifikansi untuk keadilan distributif sebesar 0,000 atau tingkat signifikansinya kurang dari 0,05 yang berarti bahwa hipotesis 1 dalam penelitian ini diterima. Sehingga dapat disimpulkan bahwa variabel keadilan distributif mempunyai pengaruh positif terhadap kecurangan akuntansi pada SKPD Kabupaten Maros. Hasil penelitian ini membuktikan bahwa keadilan distributif berpengaruh positif terhadap kecurangan akuntansi pada SKPD Kabupaten Maros. Hasil ini didukung oleh hasil analisis deskriptif yang menunjukkan bahwa sebagian besar responden memberikan jawaban bahwa keadilan distributif dapat meningkatkan kecurangan akuntansi pada SKPD Kabupaten Maros.

Fraud triangel theory menyebutkan bahwa tekanan merupakan faktor yang berasal dari kondisi individu yang menyebabkan seseorang melakukan kecurangan. Tekanan dari dalam diri seseorang tersebut dapat dipengaruhi oleh lingkungan tempat bekerja. Salah satu, faktor lingkungan yang dapat menyebabkan tekanan pada seorang pegawai adalah keadilan organisasional dalam perusahaan. Keadilan tersebut berkaitan dengan perolehan reward berupa gaji atau kompensasi lain atas pekerjaannya (keadilan distributif). Hasil Penelitian ini sejalan dengan pernyataan yang dikemukakan oleh Diyah (2016) bahwa keadilan distributif mempunyai hubungan positif dengan kecenderungan kecurangan, disebabkan oleh ketidakseimbangan antara masukan (pengetahuan, keterampilan, kemampuan, pengalaman, kerajian maupun kerja keras) yang diterima berupa gaji, perlakuan ataupun pengakuan) akan menghasilkan emosi negatif yang memotivasi karyawan mengubah perilaku, sikap, kepuasan mereka bahkan lebih parah pegawai akan berusaha untuk bertindak yang menguntungkan dirinya sehingga cenderung melakukan kecurangan.

Hipotesis kedua yang di ajukan dalam penelitian ini adalah keadilan prosedural berpengaruh negatif terhadap kecurangan akuntansi. Hasil analisis regresi untuk menguji hipotesis kedua di sajikan dalam Tabel 2. 
Tabel 2. Pengaruh Keadilan Prosedural Terhadap Kecurangan Akuntansi

\begin{tabular}{ccccc}
\hline & \multicolumn{2}{c}{$\begin{array}{c}\text { Unstandardized } \\
\text { Coefficients }\end{array}$} & $\begin{array}{c}\text { Standardized } \\
\text { Coefficients }\end{array}$ & \\
\hline Model & $\mathrm{B}$ & Std. Error & Beta & $\mathrm{t}$ \\
\hline (Constant) & 4.973 & .385 & & 12.914 \\
\hline $\mathrm{X} 2$ & .446 & .094 & -.217 & -2.082 \\
\hline
\end{tabular}

Berdasarkan hasil uji parsial di atas, persamaan regresi pengaruh keadilan prosedural terhadap kecenderungan kecurangan akuntansi pada SKPD Kabupaten Maros dapat dituliskan dalam persamaan regresi sebagai berikut, kecenderungan kecurangan akuntansi $=4,973-0,195 \mathrm{X}_{2}$. Nilai konstanta 0,195 yang negatif dan dapat diketahui nilai t hitung sebesar -2,082 lebih besar dari nilai $t$ tabel sebesar 1,662 nilai signifikansi untuk keadilan prosedural sebesar 0,040 atau tingkat signifikansinya kurang dari 0,05 yang berarti bahwa hipotesis 2 dalam penelitian ini diterima. Sehingga dapat disimpulkan bahwa variabel keadilan prosedural mempunyai pengaruh negatif terhadap kecurangan akuntansi pada SKPD Kabupaten Maros. Hasil penelitian ini membuktikan bahwa keadilan prosedural berpengaruh negatif terhadap kecurangan akuntansi pada SKPD Kabupaten Maros, hal ini dapat dilihat dari hasil analisis deskriptif yang menunjukkan bahwa sebagian besar responden memberikan jawaban setuju apabila keadilan prosedural tinggi maka kecenderungan kecurangan akuntansi rendah pada SKPD Kabupaten Maros.

Fraud triangel theory menyebutkan bahwa keadilan procedural yaitu keadilan tentang proses yang sesuai dan prosedur organisasi yang digunakan untuk membuat keputusan alokasi dan sumber (keadilan prosedural). Jika seorang pegawai merasakan ketidakadilan dalam dirinya, membuat pegawai cenderung merasa tidak puas bahkan tertekan. Jika hal tersebut terjadi, pagawai melakukan sesuatu agar dirinya puas, seperti dengan melakukan kecurangan. Hasil penelitian ini mendukung penelitian Puspitadewi dan Irwandi (2012) dan Najahningrum (2013) yang menemukan bahwa keadilan prosedural berpengaruh negatif terhadap kecurangan akuntansi.

Hipotesis ketiga yang di ajukan dalam penelitian ini adalah pertimbangan etika memoderasi pengaruh keadilan dsitributif terhadap kecurangan akuntansi. Hasil pengujian hipotesis ketiga disajikan dalam Tabel 3.

Tabel 3. Interaksi Antara Keadilan Distributif dan Pertimbangan Etika Terhadap Kecurangan Akuntansi

\begin{tabular}{cccccc}
\hline \multicolumn{7}{c}{$\begin{array}{c}\text { Unstandardized } \\
\text { Coefficients }\end{array}$} & $\begin{array}{c}\text { Standardized } \\
\text { Coefficients }\end{array}$ & & \\
\hline Model & $\mathrm{B}$ & Std. Error & Beta & t & Sig. \\
\hline (Constant) & -3.432 & 4.511 & & -.761 & .449 \\
\hline $\mathrm{X} 1$ & 1.795 & 1.083 & 1.586 & 1.657 & .101 \\
\hline $\mathrm{X} 3$ & 1.366 & 1.073 & 1.224 & 1.273 & .206 \\
\hline Moderat1 & -.322 & .255 & -2.053 & -1.262 & .210 \\
\hline
\end{tabular}

Hasil uji parsial diatas, dapat dituliskan ke dalam persamaan regresi, kecurangan akuntansi $=-3,432+1,795 \mathrm{X}_{1}+1,366 \mathrm{X}_{3}-0,322$ Moderat 1 . Makna dari Moderat 1 merupakan interaksi yang diukur dengan nilai absolut perbedaan nilai antara variabel keadilan distributif dan variabel pertimbangan etika. Semakin besar perbedaan tersebut semakin besar pengaruhnya terhadap kecurangan akuntansi. Nilai konstanta 3,432 yang negatif dan nilai signifikansi sebesar 0,210 atau tingkat signifikansinya lebih besar dari 0,05 berarti bahwa hipotesis 3 dalam penelitian ini ditolak. Sehingga dapat disimpulkan bahwa variabel pertimbangan etika tidak mampu memoderasi hubungan keadilan distributif dengan kecurangan akuntansi pada SKPD Kabupaten Maros. Hal ini dapat dilihat nilai $t_{\text {hitung }}$ sebesar $-1,268<$ dari nilai $t_{\text {tabel }}$ sebesar 1,666 dan nilai signifikansi 0,210 atau lebih besar dari 0,05. Hasil penelitian ini mendukung hasil penelitian Pristiyanti (2012) dan Aisah (2015) yang 
menyatakan bahwa keadilan distributif tidak berpegaruh terhadap kecenderungan kecurangan akuntansi.

Hipotesis keempat yang diajukan dalam penelitian ini adalah pertimbangan etika memoderasi pengaruh keadilan prosedural terhadap kecurangan akuntansi. Hasil pengujian hipotesis keempat disajikan dalam Tabel 4.

Tabel 4. Interaksi Keadilan Prosedural dan Pertimbangan Etika Terhadap Kecurangan Akuntansi

\begin{tabular}{cccccc}
\hline \multicolumn{1}{c}{$\begin{array}{c}\text { Unstandardized } \\
\text { Coefficients }\end{array}$} & $\begin{array}{c}\text { Standardized } \\
\text { Coefficients }\end{array}$ & & \\
\hline Model & $\mathrm{B}$ & Std. Error & Beta & $\mathrm{t}$ & Sig. \\
\hline (Constant) & -4.288 & 4.615 & & -.929 & .355 \\
\hline $\mathrm{X} 2$ & 1.803 & 1.168 & 2.000 & 1.544 & .126 \\
\hline $\mathrm{X} 3$ & 2.204 & 1.056 & 1.974 & 2.087 & .040 \\
\hline Moderat2 & -.475 & .266 & -3.267 & -1.789 & .077 \\
\hline
\end{tabular}

Hasil uji parsial diatas, dapat dituliskan ke dalam persamaan regresi, kecurangan akuntansi $=-4,288+1,803 \mathrm{X}_{2}+2,204 \mathrm{X}_{3}-0,475_{\text {Moderat2 }}$. Moderat 2 merupakan interaksi yang diukur dengan nilai absolut perbedaan nilai antara variabel keadilan prosedural dan variabel pertimbangan etika. Semakin besar perbedaan tersebut maka semakin besar pengaruhnya terhadap kecurangan akuntansi. Nilai konstanta 4,288 yang negatif dan nilai signifikansi sebesar 0,007 dengan tingkat signifikansinya kurang dari 0,05 berarti hipotesis 4 dalam penelitian ini diterima. Hasil penelitian ini membuktikan bahwa keadilan prosedural berpengaruh terhadap kecenderungan kecurangan akuntansi yang dimoderasi oleh pertimbangan etika pada SKPD Kabupaten Maros. Hal ini dapat dilihat nilai $t_{\text {hitung }}$ sebesar $-1,789>$ dari nilai $\mathrm{tt}_{\mathrm{abel}}$ sebesar 1,666 dan nilai signifikansi 0,077 atau kurang dari 0,05. Hasil penelitian ini membuktikan bahwa pertimbangan etika sebagai suatu pedoman yang dimiliki oleh pegawai dalam menjalankan kebijakan publik agar menghasilkan suatu pemerintahan yang baik mampu memoderasi hubungan keadilan prosedural dengan kecenderungan kecurangan akuntansi.

\section{SIMPULAN}

Hasil pengujian menunjukkan bahwa hipotesis 1 yang diajukan dalam penelitian ini terbukti. Ini berarti bahwa keadilan distributif berpengaruh positif terhadap kecurangan akuntansi pada SKPD Kabupaten Maros. Hasil pengujian kedua menunjukkan bahwa hipotesis yang diajukan dalam penelitian ini terbukti. Ini berarti bahwa keadilan prosedural berpengaruh negatif terhadap kecurangan akuntansi pada SKPD Kabupaten Maros. Tekanan merupakan faktor yang berasal dari kondisi individu yang menyebabkan seseorang melakukan kecurangan. Salah satu, faktor lingkungan yang dapat menyebabkan tekanan pada seorang pegawai adalah mengenai keadilan organisasional dalam perusahaan. Keadilan tersebut berkaitan dengan reward berupa gaji atau kompensasi lain atas pekerjaannya (keadilan distributif) dan berkaitan dengan keadilan tentang proses yang sesuai dan prosedur organisasi yang digunakan untuk membuat keputusan alokasi dan sumber (keadilan prosedural).

Hasil pengujian menunjukkan bahwa pertimbangan etika tidak memoderasi pengaruh keadilan distributif terhadap kecenderungan akuntansi. Hasil pengujian menunjukkan bahwa pertimbangan etika memoderasi pengaruh keadilan prosedural terhadap kecurangan akuntansi. Berdasarkan hasil penelitian yang telah dilakukan terlihat bahwa variabel keadilan prosedural dan keadilan distributif masih perlu ditingkatkan pada SKPD Kabupaten Maros. Peneliti selanjutnya agar dapat memperluas variabel independen yang akan di teliti seperti moralitas individu dan sistem pengendalian internal. Hasil penelitian ini membuktikan bahwa pertimbangan etika sebagai suatu pedoman yang dimiliki oleh pegawai dalam menjalankan kebijakan publik agar menghasilkan suatu pemerintahan yang baik mampu memoderasi hubungan keadilan prosedural dengan kecenderungan kecurangan akuntansi. 


\section{DAFTAR RUJUKAN}

Aisah, Fachrunisa. 2015. Pengaruh Keefektifan Pengendalian Internal, Keadilan Distributif, Keadilan Prosedural, dan Budaya Etis Organisasi terhadap Kecenderungan Kecurangan (Fraud) Akuntansi. Jom FEKON Vol. 2, No. 2. 1-15.

Ghozali, Imam. 2009. Aplikasi Analisis Multivariate dengan Program SPSS. Semarang: BPUniversitas Diponogoro.

Indonesia Corruption Watch (ICW). 2015. Jumlah Kasus Korupsi. Jakarta: ICW.

Ivancevich. 2006. Perilaku dan Manajemen Organisasi. Jakarta: Erlangga.

Kadaruddin. 2012. Pengaruh Keadilan Distributif, Keadilan Prosedural, dan Keadilan Interaksional terhadap Kepuasan Pegawai Pajak Kota Makassar. Laporan Penelitian. Universitas Hasanuddin.

Kurniawati, Ema. 2012. Analisis Faktor-Faktor yang Mempengaruhi Financial Statement Fraud dalam Perspektif Fraud Triangle. Skripsi. Universitas Diponegoro, Semarang.

Najahningrum, Anik Fatun. 2013. Faktor-faktor yang Mempengaruhi Fraud: Persepsi Pegawai Dinas Provinsi DIY. Accounting Analysis Journal 2. 3. 259-267

Pristiyanti, Ika Ruly. 2012. Persepsi Pegawai Instansi Pemerintah Mengenai Faktor-Faktor yang Mempengaruhi Fraud di Sektor Pemerintahan. Accounting Analysis Journal.

Salman, Khairansyah. 2005. Audit Investigatif; Metoda Efektif dalam Pengungkapan Kecurangan. Makalah Seminar Nasional Auditing Forensik, PPA UGM, Yogyakarta

Sudarmo, Sawardi, T. \& Yulianto, A. 2008. Fraud Auditing. Bogor: Badan Pengawasan Keuangan dan Pembangunan.

Sugiyono. 2009. Metode Penelitian Bisnis (Pendekatan Kuantitatif, Kualitatif, dan R\&D). Bandung: Alfabeta.

Suliyanto. 2011. Ekonometrika Terapan: Teori dan Aplikasi dengan SPSS. Yogyakarta: ANDI.

Supardi. 2008. Pengaruh Budaya Organisasi terhadap Keadilan Distributif dan Keadilan Prosedural, serta Produktifitas Kerja Pegawai Hotel Berbintang di Daerah Istimewa Yogyakarta. Optimal Vol. 6, No. 1. 19-40.

Suprajadi, Lusy. 2009. Teori Kecurangan, Fraud Awareness dan Metodologi untuk Mendeteksi Kecurangan Pelaporan Keuangan. Jurnal Bina Ekonomi Vol. 13, No. 2. 52-58.

Widodo, Joko. 2001. Good Governance Telaah dari Dimensi Akuntabilitas, Kontrol Birokrasi pada Era Desentralisasi dan Otonomi Daerah. Surabaya: Insan Cendekia. 